\title{
Anticancer Activity of Cynomorium coccineum
}

\author{
Mouna Sdiri ${ }^{1,2,3}$, Xiangmin Li ${ }^{1,4}$, William W. Du ${ }^{1,3}$, Safia El-Bok ${ }^{5}$, Yi-Zhen Xie ${ }^{4,6}$, \\ Mossadok Ben-Attia ${ }^{2}$ (D) and Burton B. Yang 1,3,* \\ 1 Sunnybrook Research Institute, 2075 Bayview Avenue, Toronto, ON M4N 3M5, Canada; \\ sdiri.mouna88@gmail.com (M.S.); xiangmin227@163.com (X.L.); weidong.du@alum.utoronto.ca (W.W.D.) \\ 2 Environment Biomonitoring Laboratory (LR01/ES14), Sciences Faculty of Bizerta, University of Carthage, \\ Zarzouna 7021, Tunisia; benattia.mossadok@gmail.com \\ 3 Department of Laboratory Medicine and Pathobiology, University of Toronto, Toronto, \\ ON M5S 1A8, Canada \\ 4 State Key Laboratory of Applied Microbiology Southern China, Guangdong Provincial Key Laboratory of \\ Microbial Culture Collection and Application, Guangdong Institute of Microbiology, Guangzhou 510070, \\ China; xieyizhen@126.com \\ 5 Laboratory of Biodiversity, Biotechnologies and Climate Change (LR11/ES09), Faculty of Sciences of Tunis, \\ Tunis El-Manar University, Tunis 2092, Tunisia; safia1elbok@yahoo.fr \\ 6 Yuewei Edible Fungi Technology Co. Ltd., Guangzhou 510070, China \\ * Correspondence: byang@sri.utoronto.ca; Tel.: +1-416-480-5874
}

Received: 19 August 2018; Accepted: 22 September 2018; Published: 26 September 2018

\begin{abstract}
The extensive applications of Cynomorium species and their rich bioactive secondary metabolites have inspired many pharmacological investigations. Previous research has been conducted to examine the biological activities and numerous interesting pharmaceutical activities have been reported. However, the antitumor activities of these species are unclear. To understand the potential anticancer activity, we screened Cynomorium coccineum and Cynomorium songaricum using three different extracts of each species. In this study, the selected extracts were evaluated for their ability to decrease survival rates of five different cancer cell lines. We compared the cytotoxicity of the three different extracts to the anticancer drug vinblastine and one of the most well-known medicinal mushrooms Amaurederma rude. We found that the water and alcohol extracts of $C$. coccineum at the very low concentrations possessed very high capacity in decreasing the cancer cells viability with a potential inhibition of tumorigenesis. Based on these primitive data, we subsequently tested the ethanol and the water extracts of $C$. coccineum, respectively in in vitro and in vivo assays. Cell cycle progression and induction of programmed cell death were investigated at both biological and molecular levels to understand the mechanism of the antitumor inhibitory action of the $C$. coccineum. The in vitro experiments showed that the treated cancer cells formed fewer and smaller colonies than the untreated cells. Cell cycle progression was inhibited, and the ethanol extract of $C$. coccineum at a low concentration induced accumulation of cells in the G1 phase. We also found that the C. coccineum's extracts suppressed viability of two murine cancer cell lines. In the in vivo experiments, we injected mice with murine cancer cell line B16, followed by peritoneal injection of the water extract. The treatment prolonged mouse survival significantly. The tumors grew at a slower rate than the control. Down-regulation of c-myc expression appeared to be associated with these effects. Further investigation showed that treatment with $C$. coccineum induced the overexpression of the tumor suppressor Foxo3 and other molecules involved in inducing autophagy. These results showed that the $C$. coccineum extract exerts its antiproliferative activity through the induction of cell death pathway. Thus, the Cynomorium plants appear to be a promising source of new antineoplastic compounds.
\end{abstract}

Keywords: Cynomorium coccineum; Cynomorium songaricum; MDA-MB-MB231; B16; Foxo3; breast cancer cells; tumorigenesis; mouse survival 


\section{Introduction}

Cancer generates massive public burdens across the world, and the struggle to fight cancer and eventually find a cure is one of humankind's greatest battles. Drugs to fight cancer, and many other diseases, are discovered and developed from many different sources, which include natural products like plants. There are many drugs today that are used to fight cancer that were originally obtained from natural sources [1,2]. A large problem today is that conventional chemotherapy comes with severe side effects, such as chemical toxicity to the host cells. Thus, research is underway to study possible chemotherapy drugs that are derived from plants [3]. Cynomorium coccineum is a traditional medicinal plant used extensively in the Arab world for its positive effect on fertility and immunomodulatory activities. C. coccineum and C. songaricum, belonging to the genus Cynomorium, are the only genus in the Cynomoriaceae family. Cynomorium plants are edible and nonphotosynthetic. The species $C$. coccineum is found in Northern Africa and the Mediterranean, and has different vernacular names depending on the region. It is called "tarthuth" according to the Arab world and "Maltese mushrooms" according to Europeans. C. songaricum is native to western Asia, widely collected, sold and used in the traditional Chinese medicine. This plant is considered a longevity food by the local Chinese people. Its local name, "Bu Lao Yao", means "keeping people from becoming old" [4,5].

Over the past few decades, it has been proven that many compounds isolated from fungi and plants possess anticancer activity. The plant Cynomorium is one of them. Past biological and molecular pharmacologic studies of Cynomorium plants have demonstrated that these plants have the potential to help develop therapies that affect male reproductive function [6,7]. These plants also showed many other effects like anti-oxidative, antidiabetic, HIV-1-protease inhibitory, and immunity improving effects. This is due to the chemical constituents and bioactive compounds found in these plants such as polysaccharides, triterpenoids, steroids, lignans, alkaloids, and flavonoids [8-13].

In this study, we explored the anticancer activity of Cynomorium plants. We developed a series of experiments to illustrate the anticancer activity of $C$. coccineum. In vitro, we showed that the ethanol extract of $C$. coccineum inhibited cancer cell proliferation, survival, migration, invasion, and colony formation. In vivo, we found that the water extract of $C$. coccineum inhibited tumor growth and prolonged animal survival. These results provide a new possibility for the future development of Cynomorium plants as an effective, safe, medical drug for uptake by cancer patients. It also provides us insight to understand the molecular mechanism by which C. coccineum exerts its anticancer activity.

\section{Materials and Methods}

\subsection{Plant Materials}

Cynomorium coccineum is an edible plant found along the coasts of the Mediterranean Sea, depending on the bioclimate. C. coccineum can grow on different halophytic plants such as Atriplex halimus, Obione portulacoides, and Inula crithmoides. This plant was harvested from Bizerte, also known in English as Bizerta, the northernmost city in Africa. It is on a section of Mediterranean climate coastline close to Sardinia and Sicily. This plant was collected in Spring during the flowering period, precisely from a small coastal town in Bizerta, called Ghar al Milh, formerly known as PORTO FARINA, in the Sahel region of northeastern Tunisia. C. coccineum grows in subhumid and semi-arid coastal climates and saline soils in a large area along Mediterranean-type climate. This plant is nonphotosynthetic, which explains its color (brown-reddish for the absence of photosynthetic pigments). C. coccineum is a holo-parasite, characterized by a highly distinguishable form [8]. C. coccineum was first found and discovered by a Tunisian botanist researcher, Mounir Kasri, in 2011 in Ghar el Milh. The specimens were kept cool at about $4{ }^{\circ} \mathrm{C}$ in a portable refrigerator and transported to the laboratory within one hour. The aerial parts including the root weighed $1000 \mathrm{~g}$ and were 15-20 cm long and 4-7 cm wide. The specimens were cleaned and the residual earth removed then washed with distilled water. They were then cut into slices having a thickness of about $0.7 \mathrm{~cm}$ and dried at $50{ }^{\circ} \mathrm{C}$. The dried C. coccineum were then powdered and stored at $-20^{\circ} \mathrm{C}$. After drying, 
the weight of the dried material was about $400 \mathrm{~g}$. C. songaricum was purchased in Toronto from a store selling Chinese medicinal materials. It is grown up in Gansu Province, China. This plant also possesses significant biological functions $[6,14,15]$. The samples were carefully handled as described with $\mathrm{C}$. coccineum and stored at $-20^{\circ} \mathrm{C}$ for future use.

\subsection{Preparation of Cynomorium Plants}

The extracts of the Cynomorium plants were prepared from the aerial part using boiling water. The dried aerial part of the Cynomorium plants were ground into powders that could be passed through a sieve with 60 pores per square inch. The powder (100 g each time) was incubated with hot water $(1: 10, w / v)$ at $100^{\circ} \mathrm{C}$ for $2 \mathrm{~h}$. After cooling down, the extract was filtered. The filtrate was evaporated. The partially dried material was transferred to a drier and maintained at $60^{\circ} \mathrm{C}$ till completely dry. The dried powder was used to calculate yield. The procedure was repeated once. The dried powder was stored at $-20^{\circ} \mathrm{C}$ till use.

Cynomorium powder was extracted with $95 \%$ ethanol at a ratio of 1:5 $(w / v)$. The extract was concentrated under a vacuum. Polysaccharide macromolecules are extracted through the "Hot water extraction and alcohol precipitation" method. This method allowed extraction of the Cynomorium plants material by aqueous medium. In brief, the grounded powder was soaked in water and subject to autoclaving at $120^{\circ} \mathrm{C}$ for $20 \mathrm{~min}$. It was allowed to cool down, and then followed by centrifugation at $1000 \mathrm{rpm}$ at $4{ }^{\circ} \mathrm{C}$ for $10-15 \mathrm{~min}$. Ethanol (95\%) was added to the supernatant at the ratio of 1:5 (w/v). The mix was set at $4{ }^{\circ} \mathrm{C}$ to allow polysaccharide precipitation followed by centrifugation at $1000 \mathrm{rpm}$ at $4{ }^{\circ} \mathrm{C}$ for $10-15 \mathrm{~min}$. This step was repeated three times. The pellets were collected and dialyzed against water overnight. The contents were dried for later use. The extraction of C. coccineum was performed as described [5].

\subsection{Cell Proliferation Assay}

Cells were inoculated onto 24-well tissue culture plates at a density of $8 \times 10^{4}$ cells/well in DMEM/RPMI 1640 containing 10\% FBS with $100 \mathrm{U} / \mathrm{mL}$ penicillin/streptomycin. To examine the anticancer effect of the different extracts of the $C$. coccineum plant, we performed proliferation assays using three different human breast cancer cell lines MDA-MB-231(purchased from ATCC), MCF-7 (from ATCC), and MB468 (from ATCC), one mouse breast cancer cell 4T1, and one mouse melanoma cell line B16 (from ATCC). Four hours after cell inoculation, the extract of Cynomorium plants was added to the cultures at different concentrations $(50,75,100,150 \mu \mathrm{g} / \mathrm{mL})$. Control was the cell cultures, to which the buffer was added. We also tested the effects of the extract on non-cancer cell lines NIH3T3 fibroblasts (from ATCC) and human lung cells BEAS-2B (from ATCC). The anticancer drug Vinblastine and the medium used to dissolve the polysaccharides served as controls. Some natural products that are known to possess anticancer activities were included for comparison, such as Ganoderma lucidum (100 $\mu \mathrm{g} / \mathrm{mL})$, Amauroderma rude $(100 \mu \mathrm{g} / \mathrm{mL})$, Coriolus versicolor $(100 \mu \mathrm{g} / \mathrm{mL})$, and Ergosterol $(10 \mu \mathrm{g} / \mathrm{mL})$. The cell cultures were maintained at $37{ }^{\circ} \mathrm{C}$ containing $5 \% \mathrm{CO}_{2}$ for $48 \mathrm{~h}$. The cells were harvested and mixed with trypan blue in a 1:1 ratio for exclusion staining. Dead cells were stained as blue, while living cells could not be stained by the dye due to the presence of the intact cell membrane. The number of living cells was counted as described [16]. Each experiment was repeated for at least three times for statistical analysis.

\subsection{Cell Migration}

Wound-healing assay was performed to analyze cell migration. In brief, $4 \times 10^{5}$ cells were seeded onto 6-well dishes in DMEM medium containing 10\% FBS and were maintained at $37{ }^{\circ} \mathrm{C}$ until they reached $90 \%$ confluence. The monolayer cultures were wounded by a sterile pipette tip to create a 1-mm cell-free path. The medium was removed, and the cultures were washed with PBS. The cultures were maintained in DMEM medium containing 10\% FBS supplemented with or without Cynomorium at the concentrations indicated in the figures. Cell growth was inhibited by cell 
suppressor Mitomycin $(2 \mu \mathrm{M})$. The cell cultures were photographed under a light microscope every $24 \mathrm{~h}$. The distances between the wounding center and the front of the migrating cells were measured for statistical analysis.

\subsection{Cell Invasion}

Cell invasion experiment was performed as described [17]. Briefly, the trans-well inserts were loaded with $80 \mu \mathrm{L}$ of Matrigel (1:8 dilution) and incubated at $37^{\circ} \mathrm{C}$ for $30 \mathrm{~min}$. This allowed a gel-bed to form. The inserts were then placed onto the wells of a 24-well plate, to which $500 \mu \mathrm{L}$ of medium containing 10\% FBS had been added. MDA-MB-231 cells $\left(1 \times 10^{4}\right)$ in $100 \mu \mathrm{L}$ serum-free medium containing different concentrations of Cynomorium were gently loaded on top of each gel bed. The cultures were incubated at $37^{\circ} \mathrm{C}$ for $36 \mathrm{~h}$. The trans-well inserts were then fixed with cool methanol for $15 \mathrm{~min}$, followed by staining with Coomassie Brilliant blue. The upper Matrigel layer and cells were removed and the wells were cleaned. Cells that invaded through the Matrigel and spread onto the lower surface of the inserts were photographed under a light microscope. The stained cells were counted from representative fields for quantification.

\subsection{Cell Survival}

To determine cell viability, $1 \times 10^{5}$ cells were cultured in 10\% FBS containing DMEM in culture dishes. The cultures were maintained at $37^{\circ} \mathrm{C}$ for $12 \mathrm{~h}$. The culture medium was then removed, and the cultures were washed with PBS, followed by addition of serum-free DMEM with or without Cynomorium at the concentrations indicated in each figure. The cultures were maintained at $37^{\circ} \mathrm{C}$ for 2 or 4 days. The cells were harvested, and cell number was counted by using trypan blue staining.

\subsection{Cell Cycle Analysis}

Cell cycle was analyzed by means of the propidium iodide staining procedure, previously reported in [16]. Changes in DNA content during cell cycle progression were measured with flow cytometry. MDA-MB-231 cells were seeded at the density of $5 \times 10^{6}$ cells/well, with 2 mL culture medium containing 10\% FBS. Four hours after cell inoculation, alcohol extract of C. coccineum at the concentration of $50 \mu \mathrm{g} / \mathrm{mL}$ was added. After $48 \mathrm{~h}$ incubation, the cells were harvested and washed twice with PBS, fixed with ice-cold $70 \%$ ethanol at 4 for $1 \mathrm{~h}$ and stained with propidium iodide solution in PBS. Cytofluorimetric acquisitions and analysis of DNA contents were performed by flow cytometry (BD Biosciences, San Jose, CA, USA).

\subsection{Colony Formation}

Colony formation was performed as described [18]. Briefly, $0.66 \%$ agarose gel was loaded on each well of the 6-well tissue culture plates. After solidification, MDA-MB-231 cells $\left(1 \times 10^{3}\right.$ cells $/$ well $)$ and ethanol extract of Cynomorium plants (at the final concentrations of $0,50,100 \mu \mathrm{g} / \mathrm{mL}$ ) were mixed with low melting agarose in DMEM supplemented with 10\% FBS to obtain a final concentration of $0.3 \%$ agarose. The mixtures were plated on the top of the $0.66 \%$ agarose gel. Colony formation was monitored frequently. Twenty days after cell inoculation, the colonies were examined under a light microscope. For colony staining, the colony-containing agarose gel was prefixed with $80 \%$ methanol for $30 \mathrm{~min}$, followed by staining with $0.25 \%$ Coomassie Blue for $2-4 \mathrm{~h}$, until a uniform blue color was obtained. The gel was distained with $5 \%$ methanol, followed by washing in $10 \%$ acetic acid until background was clear. Colonies were photographed under a light microscope.

\subsection{Western Blot}

After being treated with the alcohol extract of $C$. coccineum, cells were lysed by the lysis buffer containing protease inhibitor (MilliporeSigma, Burlington, MA, USA) on ice for $30 \mathrm{~min}$, followed by centrifugation to obtain clear cell lysates. Protein concentrations were determined by Bio-Rd Dc 
protein assay. Samples with equal amounts of proteins were subject to separation by SDS-PAGE and transferred onto a nitrocellulose membrane (Bio-Rd, Hercules, CA, USA). After blocking with 5\% milk, the membrane was incubated with primary antibodies at $4{ }^{\circ} \mathrm{C}$ overnight. Next day, the membrane was washed three times. The membrane was then incubated with secondary antibody for $2 \mathrm{~h}$ and washed three times again. The membrane was developed with an ECL kit (MilliporeSigma, Burlington, MA, USA) and visualized using the Kodak Image Station 4000R (Kodak, Rochester, NY, USA) as described [19].

\subsection{Real-Time PCR}

Total RNA was extracted using Total RNA Mini kit as described [20]. The concentrations of RNAs were measured by NanoDrop 2000c UV-VIS Spectrophotometer (Thermo Scientific, Waltham, MA, USA) under $260 \mathrm{~nm}$. Equal amounts of RNA were subject to reverse transcription using SuperScript III First-Strand Synthesis System (Invitrogen, Carlsbad, CA, USA) to obtain cDNAs. The cDNAs were diluted (1:5 dilutions) and used as templates for PCR using a SYBR Green PCR Kit (QIAGEN). Real-time PCR was performed for 40 cycles as follows: denaturation at $95^{\circ} \mathrm{C}$ for $30 \mathrm{~s}$, annealing at $59{ }^{\circ} \mathrm{C}$ for $30 \mathrm{~s}$, and elongation at $72{ }^{\circ} \mathrm{C}$ for $30 \mathrm{~s}$ (ABI PRISM 7700 Sequence Detection System, Thermo Scientific, Waltham, MA, USA). The mRNA levels were analyzed using U6 as an internal control. The assay was performed in triplicate $[18,21]$. The primers for Foxo3 mRNA were 27.46.hu.Foxo3-F (5' gttcgctggccgcacgtcttc) and 27.48.hu.Foxo3-R (5'ggagggacgtggacgccgcga). The primers used for U6 were 19-19-Hu-U6RNA-F (5' caccgtgctcgcttcggcagcacatatac) and 19-20-Hu-U6RNA-R (5'accgtgcaccggcgtataaacgtggtgta).

\subsection{Animal Survival Experiment}

Four-week old mice were purchased from Charles River. We used a technique established in our laboratory previously [22,23]. The animals were kept in the Animal Core Facility of Sunnybrook Research Institute for one week before use. The mice were randomly divided into 2 groups. Twenty mice were injected intraperitoneally with tumor cells B16 $\left(1 \times 10^{4}\right.$ cells $/$ mouse $)$. Three days after tumor cell injection and until palpable tumor formation, C. coccineum was injected intraperitoneally at a dose of $50 \mathrm{mg} / \mathrm{kg}$ mouse. The concentration of $C$. coccineum extract we routinely obtained was $100 \mathrm{mg} / \mathrm{mL}$ dissolved in DMSO. To have the concentration of $50 \mathrm{mg} / \mathrm{kg}$ mouse, a mouse received $1 \mathrm{mg}$ C. coccineum. We diluted the initial product 10 times to obtain $10 \mathrm{mg} / \mathrm{mL}$ using distilled water. Thus, $100 \mu \mathrm{L}$ was needed per mouse. This was repeated every other day for up to 20 days. The control group was mice injected with DMSO diluted 10 times in distilled water at the same volume and on the same schedule. All animal experiments were conducted according to the guideline approved by the Animal Care Committee at Sunnybrook Research Institute (ethic code 2017-076).

\section{Results and Discussion}

\subsection{Cynomorium Coccineum Induces Cancer Cell Death by Modulating Cell Cycle Progression}

Cynomorium coccineum has long been known as a medicinal tonic, which has been documented in different cultures. For instance, the plant is regarded as a remedy for various diseases and has been known to be used as an antihaemorrhoidal agent, a spermatogenesis stimulating agent, and an aphrodisiac. Additionally, the plant has been used as a tonic and shown antivomitive and hypotensive effects $[9,24,25]$. Some of the effects have been confirmed in studies using animal models [24,26]. The "fungus" plants were also used as a food, especially during periods of famine. This may be due to its relatively high content of oils rich in essential fatty acids, which are known to help people to survive $[27,28]$. The composition and lipid profile of fixed oil from dried stems of $C$. coccineum have been reported [27]. C. coccineum contains many active ingredients including anthocyanic glycosides, triterpenoid saponins, and lignans. It is known that Cynomorium coccineum var. coccineum from Sardinia contains gallic acid and cyanidin-3-O-glucoside as the main constituents [29]. 
In this study, we first dried the plant and isolated the biologically active components by hot water extraction. We also prepared an alcohol extract and polysaccharide extract. The anticancer effects of these three extracts were examined on a number of cancer cell lines. We found that the preparations from all three isolation methods were powerful in the induction of cancer cell death (Figure 1A). Using the same approaches, we also isolated the water extract, alcohol extract, and polysaccharides from C. songaricum. Their bioactivities were found similar to C. coccineum in the induction of cancer cell death (Figure 1B).
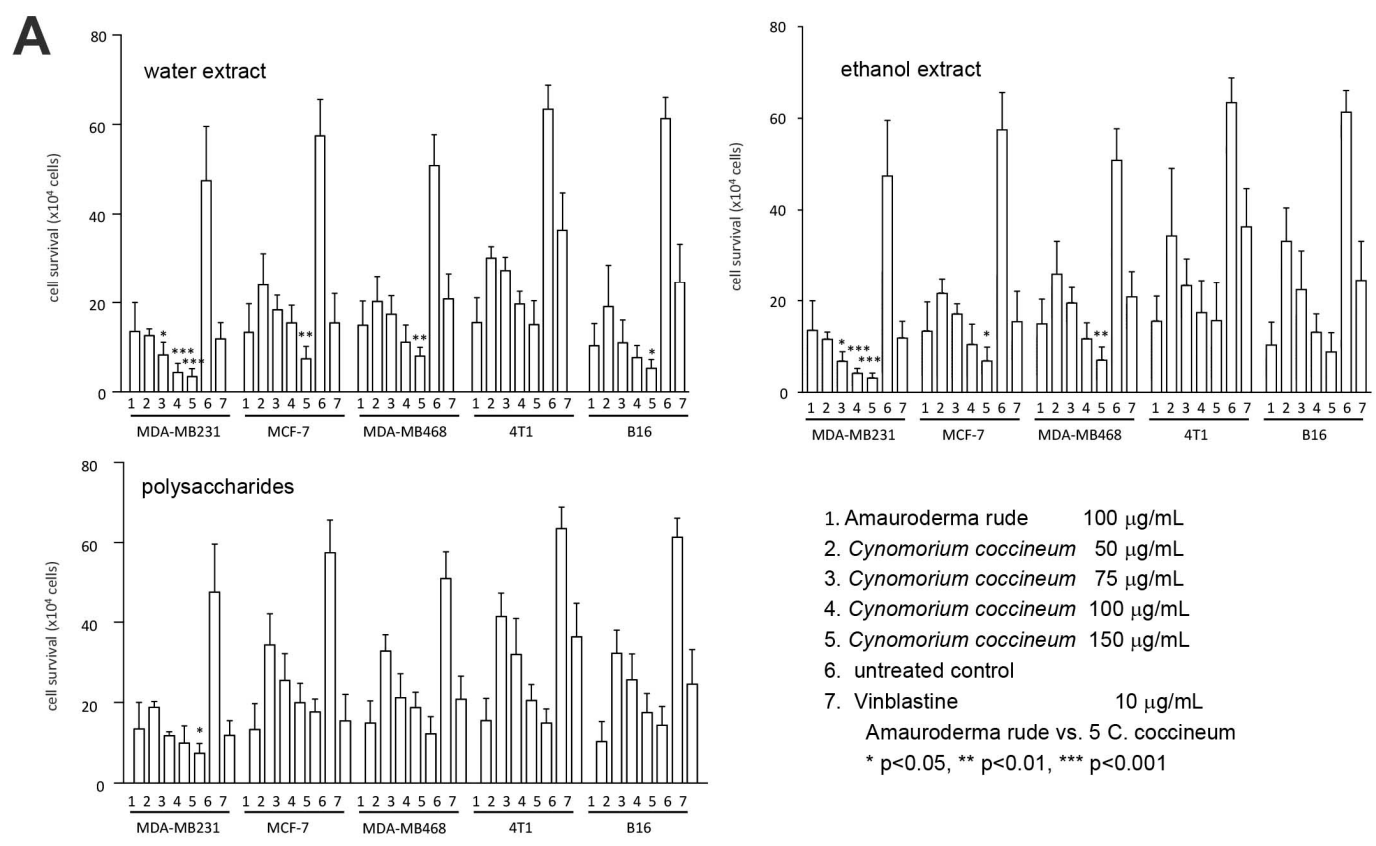

B
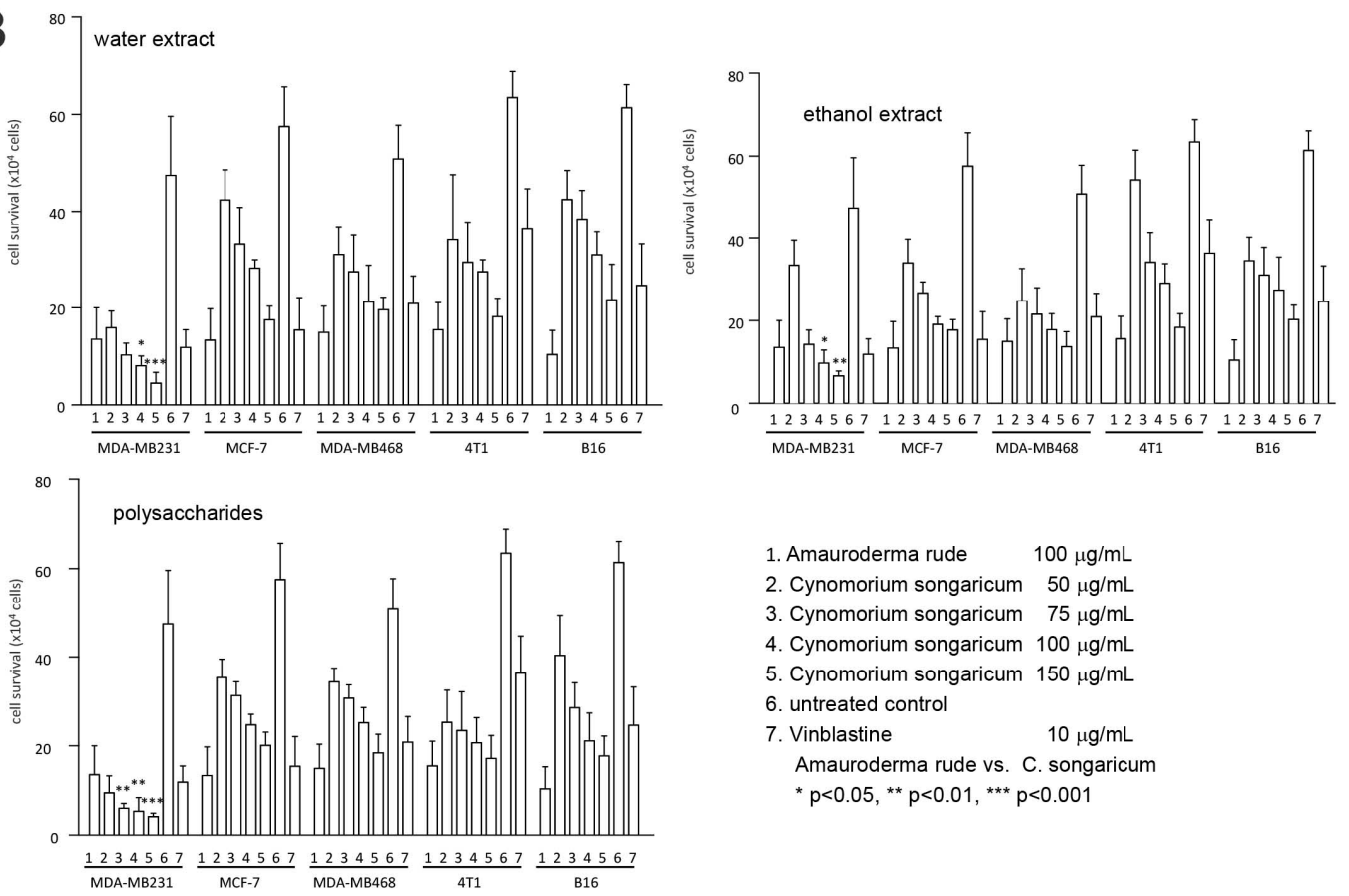

Figure 1. Comparison of bioactive components on cancer cell survival: (A) Cancer cell lines MDA-MB-231, MCF-7, MDA-MB-468, 4T1, and B16 were cultured and treated with or without Amauroderma rude, $C$. coccineum, and Vinblastine at the concentrations indicated. Cell viability was determined. (B) The cancer cell lines were cultured and treated with or without Amauroderma rude, C. songaricum, and Vinblastine at the concentrations indicated, followed by cell viability determination. 
In the half maximal inhibitory concentration $\left(\mathrm{IC}_{50}\right)$ measurements, we found that the human breast cancer cell line MDA-MB-231 was most sensitive to the ethanol extract of $C$. coccineum (with the $\mathrm{IC}_{50}$ of $30.33 \mu \mathrm{g} / \mathrm{mL}$, Figure $2 \mathrm{~A}$ ). In the mouse cell lines, B16 cells appeared to be more sensitive to the water extract of $C$. coccineum (with the $\mathrm{IC}_{50}$ of $33.86 \mu \mathrm{g} / \mathrm{mL}$ ) than $4 \mathrm{~T} 1$ cells that had an $\mathrm{IC}_{50}$ of $35.71 \mu \mathrm{g} / \mathrm{mL}$ (Figure 2B).
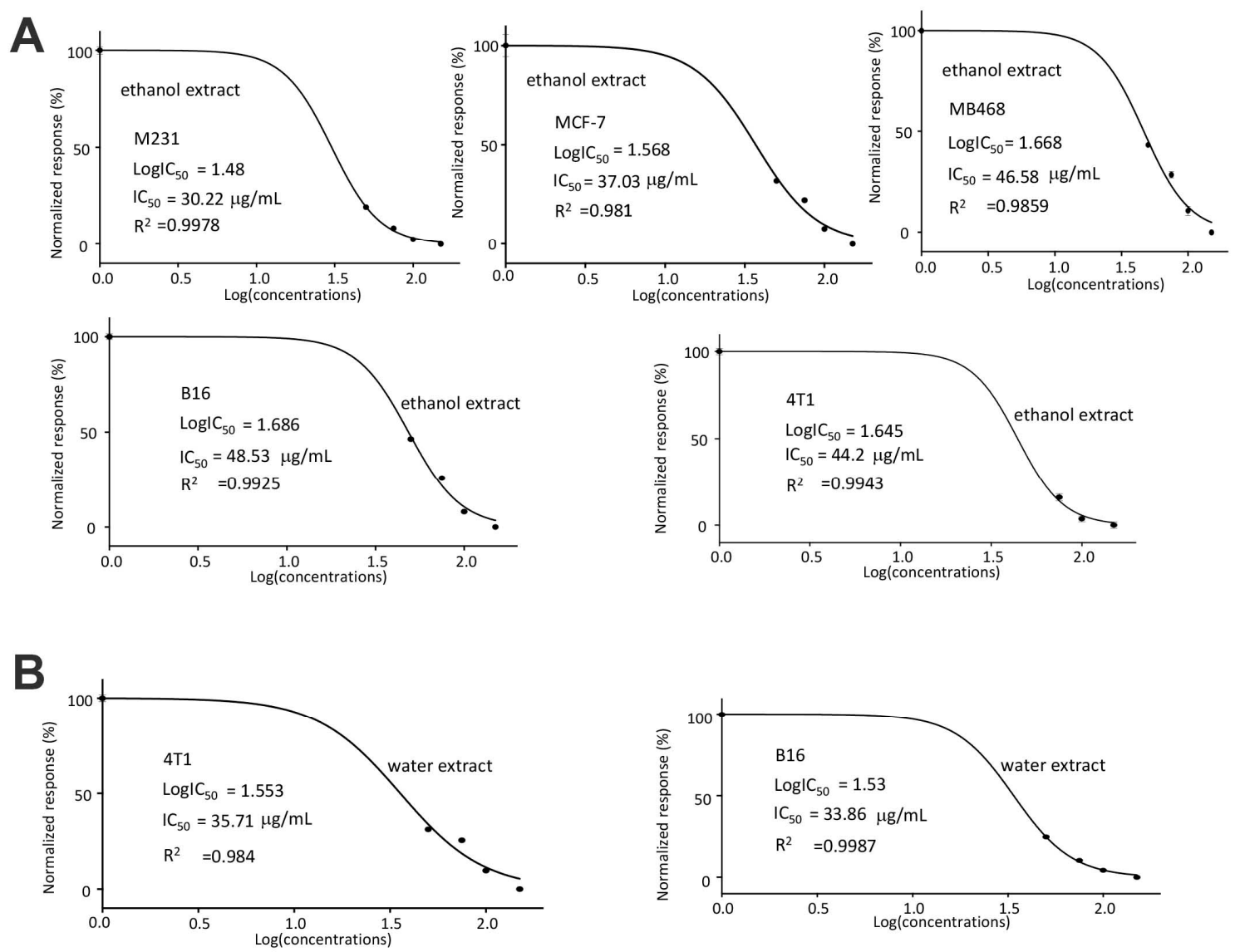

Figure 2. (A) $\mathrm{IC}_{50}$ values were calculated for MDA-MB-231, MCF-7, MDA-MB-468, B16, and $4 \mathrm{~T} 1$ after treatment with the ethanol extract of $C$. coccineum. It showed that MDA-MB-231 cells were the most sensitive cell line to the ethanol extract with an $\mathrm{IC}_{50}$ of $30.22 \mu \mathrm{g} / \mathrm{mL}$. (B) $\mathrm{IC}_{50}$ values were calculated for both B16 and $4 \mathrm{~T} 1$ after treatment with the water extract of $C$. coccineum. The B16 cells were more sensitive to the water extract than $4 \mathrm{~T} 1$ cells. $(33.86 \pm 1.7942 \mu \mathrm{g} / \mathrm{mL})$.

We thus used the human breast cancer cell line MDA-MB-231 for further study. Untreated MDA-MB-231 cells cultured in DMEM containing 10\% FBS were used as a negative control. MDA-MB-231 cells treated with the anticancer drug Vinblastine served as a positive control. We have previously demonstrated that Ganoderma lucidum, Amauroderma rude, Coriolus versicolor, and Ergosterol possess anticancer effects [30-34]. Thus, these products were included in our assay as controls. We found that Cynomorium plants were the most effective agents in inducing cancer cell death (Figure 3A). We found that the extracts obtained from water and ethanol incubation were equally effective on inducing cancer cell death. We also noted that the ethanol extract was more stable in activity than the water extract. We thus used the ethanol extract of $C$. coccineum in our further experiments. Since the assays were performed in the serum-free culture medium which is considered as a stressful environment, addition of ethanol extract of $C$. coccineum at the concentrations of 50 or $100 \mu \mathrm{g} / \mathrm{mL}$ significantly reduced cancer cell viability as compared with the buffer control. It is previously reported that Amauroderma rude is a well-known medicinal mushroom which exerted a very strong activity in inducing cancer cell death $[30,34,35]$. Our study showed that Cynomorium possessed 
even stronger anticancer activity. Recently, it was shown that the water extract of $C$. coccineum possesses antioxidant activities [36]. In addition, different components from this species also exert antimicrobial and antityrosinase activities [37].
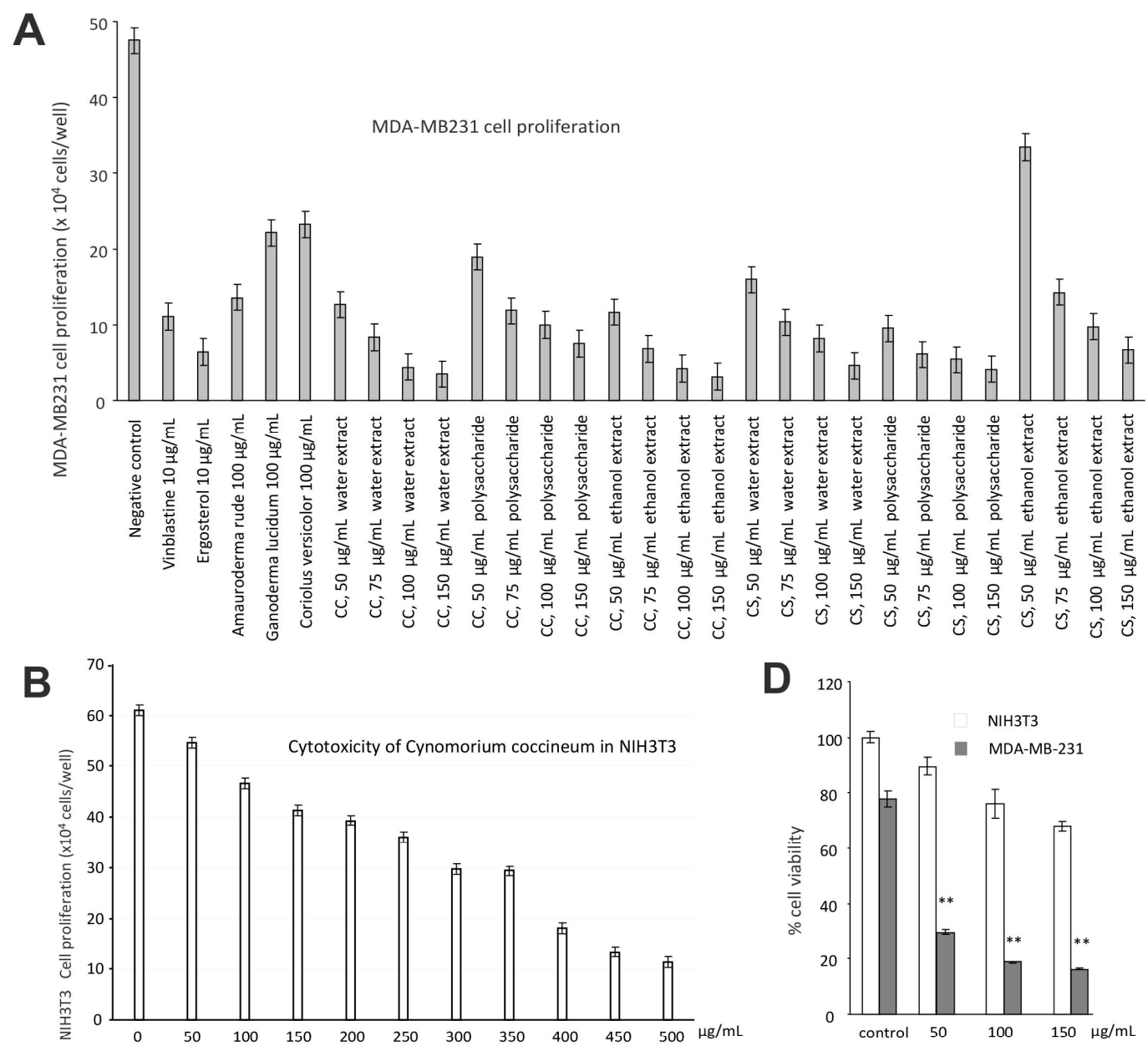

\section{C}

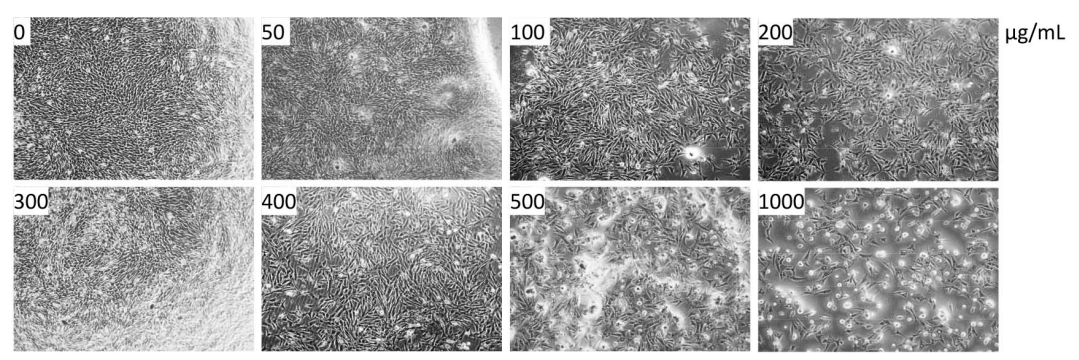

Figure 3. C. coccineum inhibits cancer cell proliferation: (A) MDA-MB-231 cells were cultured in tissue culture plates to subconfluency, to which the extracts of C. coccineum and C. songaricum were added at the concentrations as indicated. Vinblastine, ergosterol, extracts of Ganoderma lucidum, Amauroderma rude, and Coriolus versicolor were used as controls. The negative control contained the buffer alone. The extracts of Cynomorium plants were the most effective agents in inducing cancer cell death. (B) The effects of C. coccineum on the non-cancer cell line NIH3T3 fibroblasts were tested. Very high concentrations of $C$. coccineum were needed to induce cell death. (C) Typical photos of NIH3T3 fibroblasts treated with C. coccineum are shown. (D) The effects of $C$. coccineum are compared in NIH3T3 fibroblasts and MDA-MB-231 cells. C. coccineum possesses significantly stronger activity in inducing cell death in MAD-MB-231 cells relative to NIH3T3 fibroblasts. ${ }^{* *} p<0.01$. 
We tested the specificity of the ethanol extract of $C$. coccineum by using a noncancer cell line, NIH3T3 fibroblasts. Very high concentrations of $C$. coccineum were needed to induce cell death in these cells (Figure 3B). Even at higher concentrations, the ethanol extract of $C$. coccineum appeared to inhibit the growth of NIH3T3 fibroblasts, but there was a lesser sign of cell death (cell fragmentation) that could be seen (Figure 3C). We compared the effects of ethanol extract of $C$. coccineum on both groups of cells, cancer and noncancer. It showed that at the concentrations of $100 \mu \mathrm{g} / \mathrm{mL}$, the ethanol extract of $C$. coccineum displayed significantly stronger activity on inducing the death of the cancer cells, compared to the noncancer cells (Figure 3D).

We found that ninety percent of cancer cells died when they were treated with $100 \mu \mathrm{g} / \mathrm{mL}$ of the ethanol extract of $C$. coccineum. Our results suggest that the polysaccharides are not the major active component in the medicinal plant possessing anticancer activity. The non-polysaccharide fraction may play an essential role in inducing cancer cell death. Thus, we used the ethanol extract in our studies. The addition of ethanol extract at the concentrations of 50 or $100 \mu \mathrm{g} / \mathrm{mL}$ significantly induced cell death as compared with the buffer control (Figure 4A). These cells initially detached from the tissue culture plates and then died (Figure 4B). Morphologically, the detached cells appeared fragmented and as typically apoptotic cells (Figure 4C).

A
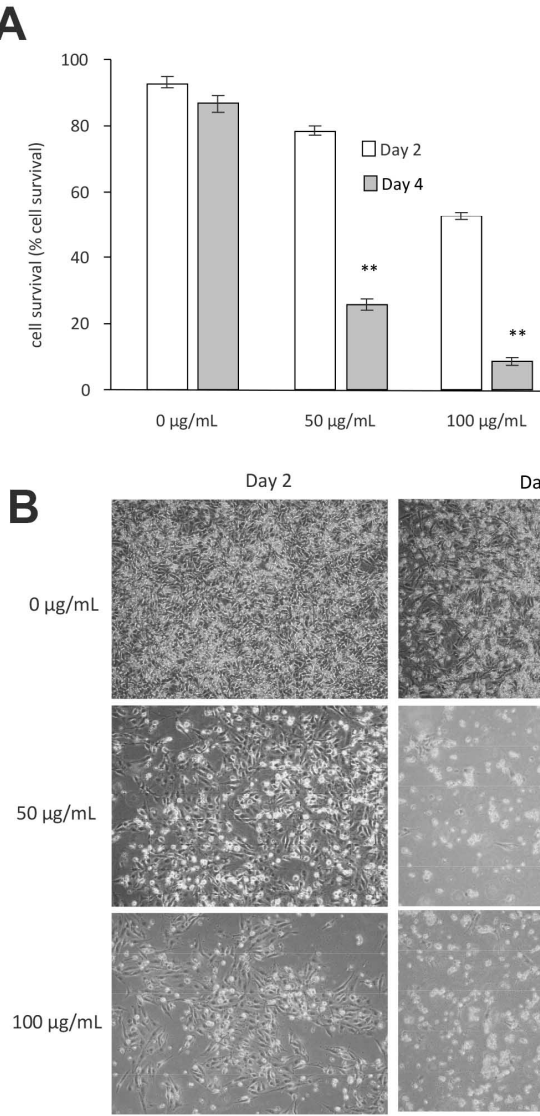

C

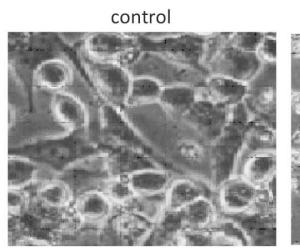

D
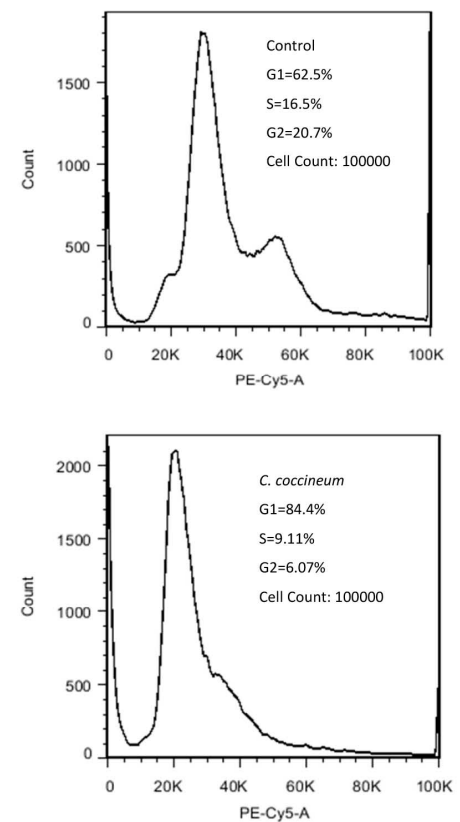

Figure 4. C. coccineum decreases cancer cell viability: (A) MDA-MB-231 cells were cultured in tissue culture plates to subconfluency in serum-free DMEM, to which the ethanol extract of $C$. coccineum was added at the concentrations as indicated. The cultures were maintained for 2 or 4 days. Addition of ethanol extract at the concentrations of 50 or $100 \mu \mathrm{g} / \mathrm{mL}$ significantly induced cell death as compared with the buffer control. (B) Typical photos showing detachment of cells from the plates treated with C. coccineum. (C) The extract of C. coccineum induced cancer cell fragmentation. (D) C. coccineum inhibits cancer cell cycle progression. We measured the cell cycle progression of the cells treated with the ethanol extract of C. coccineum $(50 \mu \mathrm{g} / \mathrm{mL}$ ). The treated cells had $84.4 \%$ of cells arrested in the G1 phase compared with un-treated cells having $62.5 \%$ in G1 phase. ${ }^{* *} p<0.01$. 
We analyzed cell cycle progression by PI staining using flow cytometry. Cell cycle analysis revealed an increased population in G1 phase after treatment with C. coccineum ( $84 \%$ vs. $62.5 \%$ ), where it showed a decrease in S and G2 phase $(9.11 \%$ and $6.07 \%$ vs. $16.5 \%$ and $20.7 \%$, respectively), compared with untreated cells (Figure 4D). The assay showed that the ethanol extract of C. coccineum at a low concentration of $50 \mu \mathrm{g} / \mathrm{mL}$ was sufficient to inhibit cell cycle progression of MDA-MB-231 cells. It showed that $84.4 \%$ of the treated cells were arrested in the G1 phase, compared with untreated cells that had $61.5 \%$ in the G1 phase.

\subsection{Cynomorium Coccineum Inhibits Cancer Cell Migration, Invasion, and Colony Formation}

We tested the effect of the ethanol extract of $C$. coccineum on cell migration in a wound healing assay. In the control, the wound gap was completely healed 2 days after wounding. Addition of the C. coccineum ethanol extracts ( 50 or $100 \mu \mathrm{g} / \mathrm{mL}$ ) inhibited the wound healing process (Figure 5A, left). Since cell proliferation was inhibited by the addition of the cell suppressor mitomycin $(2 \mu \mathrm{M})$, the process fully relied on cell migration. In the cell migration assay, the culture medium contained $10 \%$ FBS. Thus, the cells stayed in healthy conditions (Figure 5A, right). The effect of C. coccineum on inhibiting cell migration was dramatic.

In a Matrigel invasion assay, we found that the ethanol extract of $C$. coccineum displayed a significant inhibitory effect on MDA-MB-231 cell invasion at the minimum concentration of $50 \mu \mathrm{g} / \mathrm{mL}$ of extract (Figure 5B, left). In the extract-treated cultures, some cells could invade through the Matrigel, but could not spread onto the lower surface of the inserts (Figure 5B, right). Again, the invasion assay was performed in the culture medium containing $10 \%$ FBS.

We further tested the effect of the ethanol extract of $C$. coccineum on colony formation of MDA-MB-231 cells. The experiment showed that at a minimum concentration of $50 \mu \mathrm{g} / \mathrm{mL}$, the ethanol extract of $C$. coccineum significantly inhibited colony formation in both the number (Figure 5C, left) and size (Figure 5C, right) of colonies. Our results suggest that small molecules that were extracted by ethanol incubation were indeed responsible for the potent effects that the extracts had on inhibiting cell migration, invasion, and colony formation.
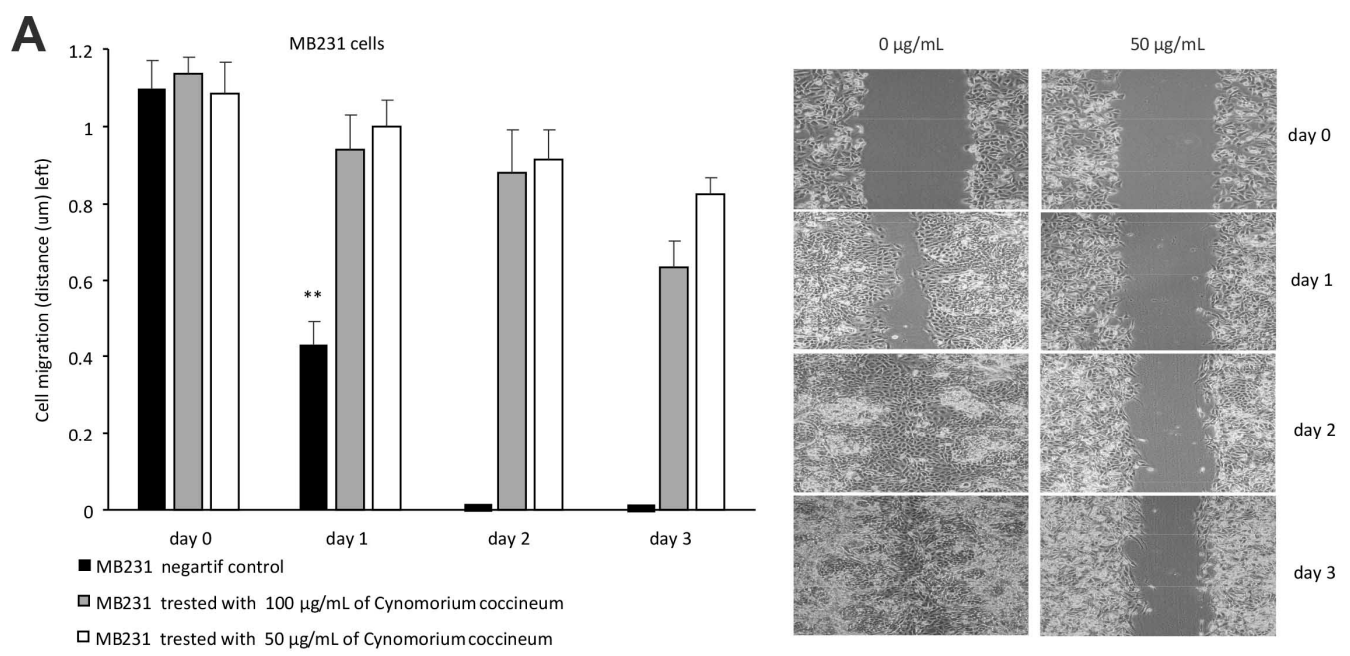

Figure 5. Cont. 
B

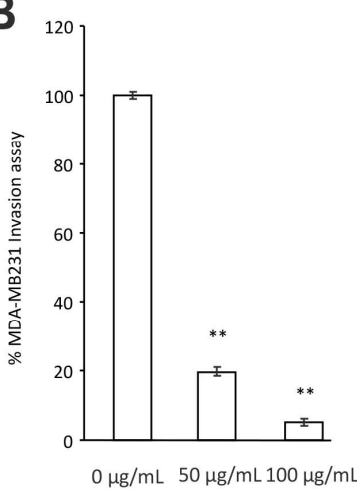

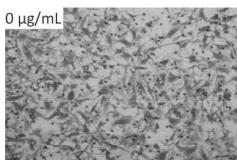

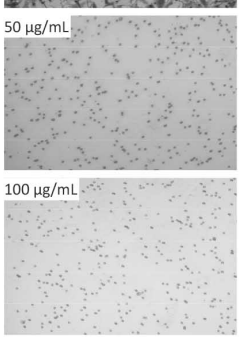

C

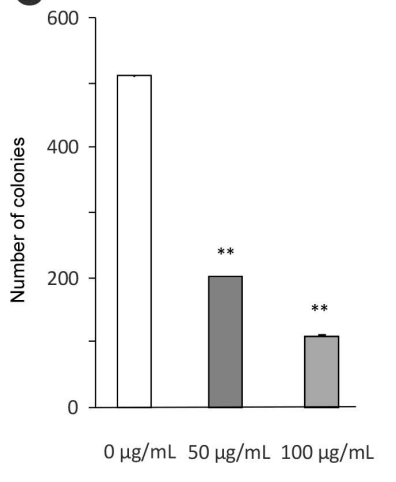

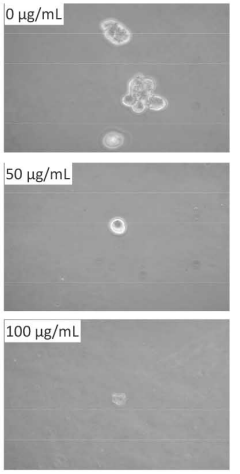

Figure 5. C. coccineum inhibits cancer cell migration, invasion, and colony formation: (A) Left, MDA-MB-231 cells were cultured in tissue culture plates to subconfluency for wound healing assay. Addition of the ethanol extracts of $C$. coccineum to the wounded cultures inhibited the healing process at 50 or $100 \mu \mathrm{g} / \mathrm{mL}$ of the extract. Right, typical photos of the cultures during the wound healing process. (B) Left, in a Matrigel invasion assay, we found that addition the extract of C. coccineum significantly inhibited MDA-MB-231 cell invasion at the minimum concentration of $50 \mu \mathrm{g} / \mathrm{mL}$ extract. Right, in the extract-treated cultures, some cells could invade through the Matrigel, but could not spread. (C) Left, in colony formation assay, MDA-MB-231 cells formed less (left) and smaller (right) colonies when the cultures were treated with C. coccineum. ${ }^{* *} p<0.01$.

\subsection{Cynomorium Coccineum Treatment Prolonged Animal Survival}

We further validated the anticancer effect of $C$. coccineum in vivo. In this assay, we adapted a mouse model of tumor formation to test the extract of $C$. coccineum. Strain C57BL mice were injected with B16 cells. B16 cells appeared to be more sensitive to the water extract compared to the ethanol extract of $C$. coccineum (Figure 2). We tested the inhibitory effect of the water extract of $C$. coccineum on tumor growth. Three days after the tumor cell injection, C. coccineum water extract was injected every other day at the concentration of $50 \mathrm{mg} / \mathrm{kg}$ mouse. On day 21 , we found that the mice treated with the water extract of $C$. coccineum displayed a significantly longer survival time than the control mice, according to the Kaplan-Meier analysis of survivor curves (Figure 6A). The mean survival time of control groups ranged from 1 to 2 weeks, while the mean time of the treated groups ranged from 1 to 3 weeks. After 21 days, four mice from the $C$. coccineum water extract treated group were still alive (Figure 6B). This data suggests that the water extract of $C$. coccineum had anticancer effects in vivo and could prolong survival rates of tumor-bearing animals, leading to a longer lifespan. This may be of clinical significance.

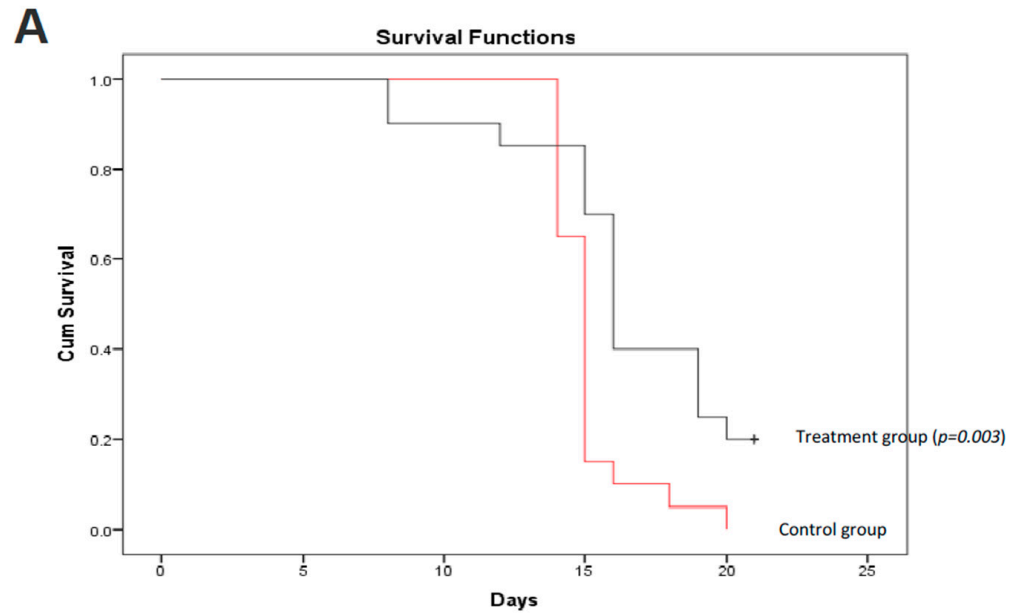

Figure 6. Cont. 
B
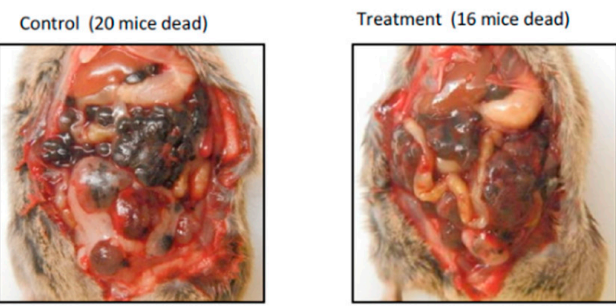

After 21 days, treatment group had 4 mice left

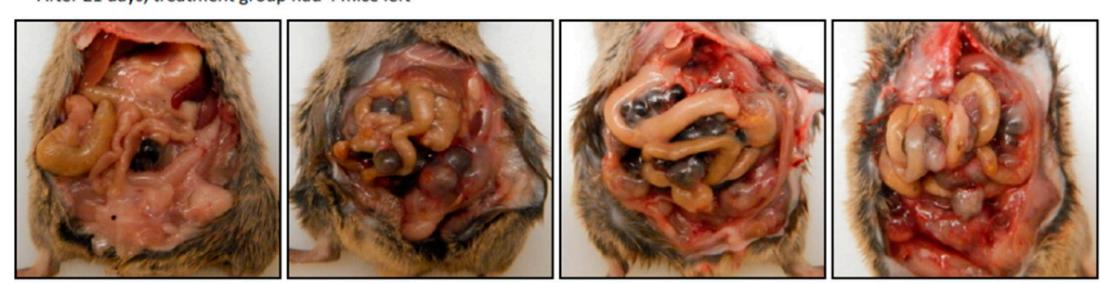

Figure 6. C. coccineum treatment prolonged animal survival. C57BL mice were injected with B16 tumor cells. Three days after cell injection, $C$. coccineum water extract was injected every other day at the concentration of $50 \mathrm{mg} / \mathrm{kg}$ mouse. Tumor development and mouse viability were monitored every other day. On day 21 , the mice treated with $C$. coccineum displayed a significantly longer viability than the control. Upper, Kaplan-Meier analysis of C. coccineum displayed survivor curves; Lower, photos showing tumors developed in the control but less in the C. coccineum-treated mice.

\subsection{Regulation of Signal Protein Expression by Cynomorium Coccineum}

We examined whether C. coccineum extract induced cancer cell apoptosis by the upregulation/ expression of tumor suppressor genes, namely the forkhead boxo3 (also known as Foxo3), a transcription factor encoded by the Foxo3 gene. Foxo3 plays pivotal roles in tumorigenesis and drug resistance. Thus, Foxo3 deregulation appears to be essential in the development of cancer.

In the cells treated with $50 \mu \mathrm{g} / \mathrm{mL}$ of ethanol extract of $C$. coccineum, Foxo3 expression was measured by real-time PCR using total RNAs isolated from MDA-MB-231 cells treated with or without the extract, using the primers listed in the Methods section. We found that Foxo3 mRNA expression was significantly upregulated as compared with the control (Figure 7A). Western blot analysis revealed that Foxo3 protein also increased in the cells treated with C. coccineum ethanol extract (Figure 7B).

We also examined expression of other proteins that are associated with Foxo3-induced cancer cell death including c-myc, pAKT, and LC3-B. Treatments with C. coccineum at the concentrations of $50 \mu \mathrm{g} / \mathrm{mL}$ and $100 \mu \mathrm{g} / \mathrm{mL}$ greatly decreased expression of these proteins (Figure $7 \mathrm{C}$ ), suggesting a role in the inhibition of tumor growth. 

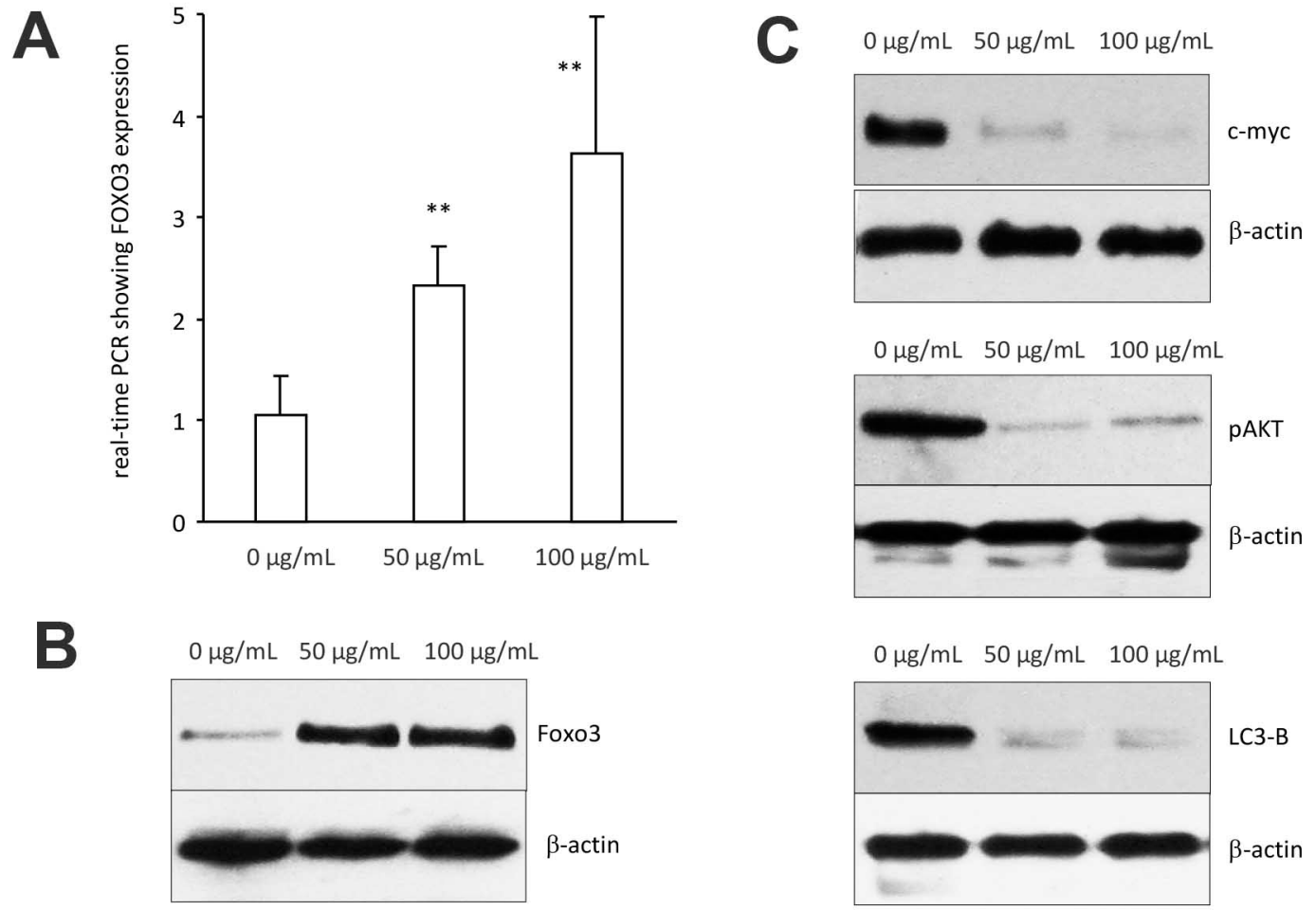

Figure 7. Expression of signal proteins affected by C. coccineum: (A) MDA-MB-231 cells were cultured to subconfluency and treated with ethanol extract of $C$. coccineum $(50 \mu \mathrm{g} / \mathrm{mL})$. Total RNAs were harvested followed by measurement of Foxo3 expression by real-time PCR. Treatment with $C$. coccineum increased Foxo3 mRNA expression. (B) Cell lysate was also prepared from the cells treated with C. coccineum followed by Western blotting probing with antiFoxo3 antibody. Similarly, treatment with C. coccineum increased Foxo3 protein expression. (C) Expression of c-myc, pAKT, and LC3-B was also analyzed in the cell lysate. Treatment with $C$. coccineum decreased expression of these proteins. ${ }^{* *} p<0.01$.

These results provide new insight for future development of Cynomorium plants as an effective and safe medicinal plant for use by cancer patients. It also provides evidence allowing us to further understand the molecular mechanism by which $C$. coccineum exerts its anticancer activity. Amongst all medicinal plants, C. coccineum and C. songaricum are two popular plants used in Asian countries and in the Arab world, especially for reproductive activity. These two plants have been widely used for the promotion of health longevity and immunomodulatory effects. We found that the anticancer activity of both $C$. coccineum and $C$. songaricum was significantly higher than that of the three well-known medicinal mushrooms (Amauroderma rude, Ganoderma lucidum, and Coriolus vesicolor). In our previous study, we found that Amauroderma rude possessed the highest anticancer activity in inducing cell death, tested in several invasive and metastatic breast cancer cell lines and other types of cancer cell lines [30]. The anticancer activities of components isolated from C. coccineum, and C. songaricum were not only better than Amauroderma rude, but also Ergosterol purified from Ganoderma lucidum, which also possessed extremely high anticancer activity. Finally, the anticancer effects of $C$. coccineum and C. songaricum were significantly stronger than the anticancer drugs Vinblastine. Our results suggest that understanding the biology and physiological roles of $C$. coccineum will soon allow this plant to be used as an adjuvant for health promotion, especially in cancer patients. Furthermore, the extracts of C. coccineum can be regarded as a valuable adjuvant for combination chemotherapy in the treatment of various cancers. Future work could lead to the purification and synthesis of the main active molecules from Cynomorium plants to improve its effective therapy in clinical settings. 


\section{Conclusions}

In vitro, $C$. coccineum possesses the highest activity in killing breast cancer cells. In vivo, C. coccineum inhibits cancer progression and prolongs mouse survival. C. coccineum induces up-regulation expression of the cancer suppressor Foxo3 and its related molecules in the signaling pathway.

Author Contributions: Conceptualization, M.S., S.E.-B., M.B.-A. and B.B.Y.; Methodology, M.S., X.L. and W.W.D.; Formal Analysis, M.S.; Data Analysis, M.S., X.L. and B.B.Y.; Writing-Original Draft Preparation, M.S.; Writing-Review \& Editing, B.B.Y.; Supervision, B.B.Y.; Project Administration, S.E.-B., Y.-Z.X. M.B.-A. and B.B.Y.; Funding Acquisition, M.S., Y.Z.X. and B.B.Y.

Funding: This work was supported by the following grants: The Introduction of Leading Talent Project of Guangdong Academy of Sciences GD2015T001, Canadian Institutes of Health Research (PJT-153105 and PJT-155962). Mouna Sdiri was supported by a studentship from Tunisia Government.

Conflicts of Interest: The authors declare no conflicts of interest.

\section{Abbreviations}

DMEM Dulbecco's modified Eagle's medium:

FBS fetal bovine serum;

PAGE Polyacrylamide gel electrophoresis.

\section{References}

1. Liu, T.; Men, Q.; Wu, G.; Yu, C.; Huang, Z.; Liu, X.; Li, W. Tetrandrine induces autophagy and differentiation by activating ROS and Notch1 signaling in leukemia cells. Oncotarget 2015, 6, 7992-8006. [CrossRef] [PubMed]

2. Wong, V.K.; Chiu, P.; Chung, S.S.; Chow, L.M.; Zhao, Y.Z.; Yang, B.B.; Ko, B.C. Pseudolaric acid B, a novel microtubule-destabilizing agent that circumvents multidrug resistance phenotype and exhibits antitumor activity in vivo. Clin. Cancer Res. 2005, 11, 6002-6011. [CrossRef] [PubMed]

3. Balachandran, P.; Govindarajan, R. Cancer-An ayurvedic perspective. Pharmacol. Res. 2005, 51, 19-30. [CrossRef] [PubMed]

4. Zhang, X.; Gu, C.; Ahmad, B.; Huang, L. Optimization of Extract Method for Cynomorium songaricum Rupr. by Response Surface Methodology. J. Anal. Methods Chem. 2017, 2017, 6153802. [CrossRef] [PubMed]

5. Liu, Y.; Li, H.; Wang, X.; Zhang, G.; Wang, Y.; Di, D. Evaluation of the free radical scavenging activity of Cynomorium songaricum Rupr. by a novel DPPH-HPLC method. J. Food Sci. 2011, 76, C1245-1249. [CrossRef] [PubMed]

6. Lee, J.S.; Oh, H.A.; Kwon, J.Y.; Jeong, M.H.; Lee, J.S.; Kang, D.W.; Choi, D. The Effects of Cynomorium songaricum on the Reproductive Activity in Male Golden Hamsters. Dev. Reprod. 2013, 17, 37-43. [CrossRef] [PubMed]

7. Yang, W.M.; Kim, H.Y.; Park, S.Y.; Kim, H.M.; Chang, M.S.; Park, S.K. Cynomorium songaricum induces spermatogenesis with glial cell-derived neurotrophic factor (GDNF) enhancement in rat testes. J. Ethnopharmacol. 2010, 128, 693-696. [CrossRef] [PubMed]

8. Ikram, M.; Dar, M.S.; Fakouhi, T. Hypotensive agent from Cynomorium coccineum. Pahlavi Med. J. 1978, 9, 167-181. [PubMed]

9. Al-Qarawi, A.A.; Abdel-Rahman, H.A.; El-Badry, A.A.; Harraz, F.; Razig, N.A.; Abdel-Magied, E.M. The effect of extracts of Cynomorium coccineum and Withania somnifera on gonadotrophins and ovarian follicles of immature Wistar rats. Phytother. Res. 2000, 14, 288-290. [CrossRef]

10. Goncalves, M.J.; Piras, A.; Porcedda, S.; Marongiu, B.; Falconieri, D.; Cavaleiro, C.; Rescigno, A.; Rosa, A.; Salgueiro, L. Antifungal activity of extracts from Cynomorium coccineum growing wild in Sardinia island (Italy). Nat. Prod. Res. 2015, 29, 2247-2250. [CrossRef] [PubMed]

11. Wang, X.; Tao, R.; Yang, J.; Miao, L.; Wang, Y.; Munyangaju, J.E.; Wichai, N.; Wang, H.; Zhu, Y.; Liu, E.; et al. Compounds from Cynomorium songaricum with Estrogenic and Androgenic Activities Suppress the Oestrogen/Androgen-Induced BPH Process. Evid.-Based Complement. Altern. Med. 2017, 2017, 6438013. [CrossRef] [PubMed] 
12. Wang, F.; Liu, Q.; Wang, W.; Li, X.; Zhang, J. A polysaccharide isolated from Cynomorium songaricum Rupr. protects PC12 cells against H2O2-induced injury. Int. J. Biol. Macromol. 2016, 87, 222-228. [CrossRef] [PubMed]

13. Ma, C.; Nakamura, N.; Miyashiro, H.; Hattori, M.; Shimotohno, K. Inhibitory effects of constituents from Cynomorium songaricum and related triterpene derivatives on HIV-1 protease. Chem. Pharm. Bull. 1999, 47, 141-145. [CrossRef] [PubMed]

14. Liu, M.; Xiao, G.G.; Rong, P.; Zhang, Z.; Dong, J.; Zhao, H.; Li, H.; Li, Y.; Pan, J.; Liu, H.; et al. Therapeutic effects of radix dipsaci, pyrola herb, and Cynomorium songaricum on bone metabolism of ovariectomized rats. BMC Complement. Altern. Med. 2012, 12, 67. [CrossRef] [PubMed]

15. Yoo, D.Y.; Choi, J.H.; Kim, W.; Jung, H.Y.; Nam, S.M.; Kim, J.W.; Yoon, Y.S.; Yoo, K.Y.; Won, M.H.; Hwang, I.K. Cynomorium songaricum extract enhances novel object recognition, cell proliferation and neuroblast differentiation in the mice via improving hippocampal environment. BMC Complement. Altern. Med. 2014, 14, 5. [CrossRef] [PubMed]

16. Du, W.W.; Yang, W.; Liu, E.; Yang, Z.; Dhaliwal, P.; Yang, B.B. Foxo3 circular RNA retards cell cycle progression via forming ternary complexes with p21 and CDK2. Nucleic Acids Res. 2016, 44, $2846-2858$. [CrossRef] [PubMed]

17. Yang, W.; Du, W.W.; Li, X.; Yee, A.J.; Yang, B.B. Foxo3 activity promoted by non-coding effects of circular RNA and Foxo3 pseudogene in the inhibition of tumor growth and angiogenesis. Oncogene 2016, 35, 3919-3931. [CrossRef] [PubMed]

18. Yang, Q.; Du, W.W.; Wu, N.; Yang, W.; Awan, F.M.; Fang, L.; Ma, J.; Li, X.; Zeng, Y.; Yang, Z.; et al. A circular RNA promotes tumorigenesis by inducing c-myc nuclear translocation. Cell Death Diff. 2017, 24, 1609-1620. [CrossRef] [PubMed]

19. Du, W.W.; Yang, W.; Chen, Y.; Wu, Z.K.; Foster, F.S.; Yang, Z.; Li, X.; Yang, B.B. Foxo3 circular RNA promotes cardiac senescence by modulating multiple factors associated with stress and senescence responses. Eur. Heart J. 2017, 38, 1402-1412. [CrossRef] [PubMed]

20. Zeng, Y.; Du, W.W.; Wu, Y.; Yang, Z.; Awan, F.M.; Li, X.; Yang, W.; Zhang, C.; Yang, Q.; Yee, A.; et al. A Circular RNA Binds To and Activates AKT Phosphorylation and Nuclear Localization Reducing Apoptosis and Enhancing Cardiac Repair. Theranostics 2017, 7, 3842-3855. [CrossRef] [PubMed]

21. Yang, Z.G.; Awan, F.M.; Du, W.W.; Zeng, Y.; Lyu, J.; Wu, D.; Gupta, S.; Yang, W.; Yang, B.B. The Circular RNA Interacts with STAT3, Increasing Its Nuclear Translocation and Wound Repair by Modulating Dnmt3a and miR-17 Function. Mol. Ther. 2017, 25, 2062-2074. [CrossRef] [PubMed]

22. Du, W.W.; Fang, L.; Yang, W.; Wu, N.; Awan, F.M.; Yang, Z.; Yang, B.B. Induction of tumor apoptosis through a circular RNA enhancing Foxo3 activity. Cell Death Diff. 2017, 24, 357-370. [CrossRef] [PubMed]

23. Fang, L.; Du, W.W.; Lyu, J.; Dong, J.; Zhang, C.; Yang, W.; He, A.; Kwok, Y.S.S.; Ma, J.; Wu, N.; et al. Enhanced breast cancer progression by mutant p53 is inhibited by the circular RNA circ-Ccnb1. Cell Death Diff. 2018. [CrossRef] [PubMed]

24. Abd el-Rahman, H.A.; el-Badry, A.A.; Mahmoud, O.M.; Harraz, F.A. The effect of the aqueous extract of Cynomorium coccineum on the epididymal sperm pattern of the rat. Phytother. Res. 1999, 13, 248-250. [CrossRef]

25. Garcia, M.A.; Nicholson, E.H.; Nickrent, D.L. Extensive intraindividual variation in plastid rDNA sequences from the holoparasite Cynomorium coccineum (Cynomoriaceae). J. Mol. Evol. 2004, 58, 322-332. [CrossRef] [PubMed]

26. Abdel-Magied, E.M.; Abdel-Rahman, H.A.; Harraz, F.M. The effect of aqueous extracts of Cynomorium coccineum and Withania somnifera on testicular development in immature Wistar rats. J. Ethnopharmacol. 2001, 75, 1-4. [CrossRef]

27. Rosa, A.; Rescigno, A.; Piras, A.; Atzeri, A.; Scano, P.; Porcedda, S.; Zucca, P.; Assunta Dessi, M. Chemical composition and effect on intestinal Caco-2 cell viability and lipid profile of fixed oil from Cynomorium coccineum L. Food Chem. Toxicol. 2012, 50, 3799-3807. [CrossRef] [PubMed]

28. Rosa, A.; Nieddu, M.; Piras, A.; Atzeri, A.; Putzu, D.; Rescigno, A. Maltese mushroom (Cynomorium coccineum L.) as source of oil with potential anticancer activity. Nutrients 2015, 7, 849-864. [CrossRef] [PubMed]

29. Zucca, P.; Rosa, A.; Tuberoso, C.I.; Piras, A.; Rinaldi, A.C.; Sanjust, E.; Dessi, M.A.; Rescigno, A. Evaluation of antioxidant potential of "maltese mushroom" (Cynomorium coccineum) by means of multiple chemical and biological assays. Nutrients 2013, 5, 149-161. [CrossRef] [PubMed] 
30. Jiao, C.; Xie, Y.Z.; Yang, X.; Li, H.; Li, X.M.; Pan, H.H.; Cai, M.H.; Zhong, H.M.; Yang, B.B. Anticancer activity of Amauroderma rude. PLoS ONE 2013, 8, e66504. [CrossRef] [PubMed]

31. Li, X.; Wu, Q.; Bu, M.; Hu, L.; Du, W.W.; Jiao, C.; Pan, H.; Sdiri, M.; Wu, N.; Xie, Y.; et al. Ergosterol peroxide activates Foxo3-mediated cell death signaling by inhibiting AKT and c-Myc in human hepatocellular carcinoma cells. Oncotarget 2016, 7, 33948-33959. [CrossRef] [PubMed]

32. Wu, Q.P.; Xie, Y.Z.; Deng, Z.; Li, X.M.; Yang, W.; Jiao, C.W.; Fang, L.; Li, S.Z.; Pan, H.H.; Yee, A.J.; et al. Ergosterol peroxide isolated from Ganoderma lucidum abolishes microRNA miR-378-mediated tumor cells on chemoresistance. PLoS ONE 2012, 7, e44579. [CrossRef] [PubMed]

33. Chen, S.; Li, X.; Yong, T.; Wang, Z.; Su, J.; Jiao, C.; Xie, Y.; Yang, B.B. Cytotoxic lanostane-type triterpenoids from the fruiting bodies of Ganoderma lucidum and their structure-activity relationships. Oncotarget 2017, 8, 10071-10084. [CrossRef] [PubMed]

34. Pan, H.; Han, Y.; Huang, J.; Yu, X.; Jiao, C.; Yang, X.; Dhaliwal, P.; Xie, Y.; Yang, B.B. Purification and identification of a polysaccharide from medicinal mushroom Amauroderma rude with immunomodulatory activity and inhibitory effect on tumor growth. Oncotarget 2015, 6, 17777-17791. [CrossRef] [PubMed]

35. Li, X.; Wu, Q.; Xie, Y.; Ding, Y.; Du, W.W.; Sdiri, M.; Yang, B.B. Ergosterol purified from medicinal mushroom Amauroderma rude inhibits cancer growth in vitro and in vivo by up-regulating multiple tumor suppressors. Oncotarget 2015, 6, 17832-17846. [CrossRef] [PubMed]

36. Attia, I.B.; Zucca, P.; Marincola, F.C.; Piras, A.; Rosa, A.; Chaieb, M.; Rescigno, A. Chemical Composition and Antioxidant Potential Differences between Cynomorium coccineum L. Growing in Italy and in Tunisia: Effect of Environmental Stress. Diversity 2018, 10, 53. [CrossRef]

37. Zucca, P.; Argiolas, A.; Nieddu, M.; Pintus, M.; Rosa, A.; Sanna, F.; Sollai, F.; Steri, D.; Rescigno, A. Biological Activities and Nutraceutical Potentials of Water Extracts from Different Parts of Cynomorium coccineum L. (Maltese Mushroom). Pol. J. Food Nutr. Sci. 2016, 66, 179-188. [CrossRef]

(C) 2018 by the authors. Licensee MDPI, Basel, Switzerland. This article is an open access article distributed under the terms and conditions of the Creative Commons Attribution (CC BY) license (http:/ / creativecommons.org/licenses/by/4.0/). 